\title{
Effects of Hot Rehydration in the Presence of Hydrogen Peroxide on Microbial Quality, Texture, Color, and Antioxidant Activity of Cold- stored Intermediate-moisture Sun-dried Figs
}

\author{
DILEK DEMIRBÜKER, ISKENDER ARCAN, FIGEN TOKATLI, AND AHMETYEMENICIOGLU
}

\begin{abstract}
Pectin methylesterase (PME) causes considerable softening in intermediate-moisture (IM) figs rehydrated at $30^{\circ} \mathrm{C}$ and cold stored at $28 \%$ to $29 \%$ moisture content. Rehydration of figs at $80^{\circ} \mathrm{C}$ for $16 \mathrm{~min}$ inactivated PME partially (25-30\%), but this did not prevent the softening over 3 mo of cold storage. Also, heating did not reduce the microbial load of figs significantly and increased their browning. In contrast, rehydration of figs 1 st in $2.5 \%$ $\mathrm{H}_{2} \mathrm{O}_{2}$ at $80^{\circ} \mathrm{C}$ for $8 \mathrm{~min}$ and then in water at $80^{\circ} \mathrm{C}$ for $8 \mathrm{~min}$ reduced the microbial load of IM figs significantly, turned their brown color to yellow-light brown, and maintained their desired textural properties. $\mathrm{The}$ residual $\mathrm{H}_{2} \mathrm{O}_{2}$ in IM figs decomposed in 3 or $1.5 \mathrm{wk}$ by the in situ catalase or by application of the iron (II) sulfate-ascorbic acid residue elimination method, respectively. Hot rehydration did not affect the antioxidant activity of IM figs, but treatment of figs with $\mathrm{H}_{2} \mathrm{O}_{2}$ increased their antioxidant activity slightly. These results indicate that the hot rehydration of figs in the presence of $\mathrm{H}_{2} \mathrm{O}_{2}$ and cold storage may be applied to obtain safe and $\mathrm{SO}_{2}$-free light-colored IM fig products.
\end{abstract}

Keywords: figs, hydrogen peroxide, microbial load, texture, antioxidant activity

\section{Introduction}

$S^{u}$ un-dried figs generally contain $15 \%$ to $20 \%$ moisture (Desai and Kotecha 1995), and with their characteristic gummy texture, they may be consumed directly or may be used as ingredients for different products such as breakfast cereals, cereal bars, and confectionaries. In recent years, industry and consumer demand for intermediate-moisture (IM) fruits has increased the application of rehydration of sun-dried fruits to $25 \%$ to $40 \%$ moisture (Cemeroglu 1986; Desai and Kotecha 1995; Simmons and others 1997). IM fruits are more suitable for direct consumption, and they may be used as an ingredient in the production of dairy and bakery products. Moreover, IM fruit pieces or purees may be used in salads, fruit drink formulations, preserves, jams, or jellies (de Daza and others 1997).

IM fruits are generally stabilized by chemical preservatives such as sorbates, sulfites, or benzoates (Cemeroglu 1986; de Daza and others 1997) or thermal processing (Cemeroglu 1986; Desai and Kotecha 1995). However, the increasing health concerns of consumers toward foods stabilized by chemical preservatives, as well as the unsatisfactory sensory and nutritional properties of thermally processed foods, have forced the dried-fruit industry to seek alternative preservation methods (de Daza and others 1997; WeltiChanes and others 1997). For example, El Halouat and others (1998) applied modified atmosphere packaging in combination with mild heating and low concentrations of preservatives such as sorbates and benzoates to increase the shelf-life of rehydrated IM

MS 20040365 Submitted 6/3/04, Revised 7/26/04, Accepted 8/27/04. The authors are with Dept. of Food Engineering, Faculty of Engineering, Izmir Inst. of Technology, 35430, Gülbahçe Köyü, Urla, Izmir, Turkey. Direct inquiries to author Yemenicioglu (E-mail:ahmetyemenicioglu@iyte.edu.tr). prunes and raisins. Also, some successful studies have been conducted to reduce the microbial load of dried fruits such as raisins and plums with vapor-phase $\mathrm{H}_{2} \mathrm{O}_{2}$ disinfection (Simmons and others 1997; Sapers and Simmons 1998). $\mathrm{H}_{2} \mathrm{O}_{2}$ is a Generally Recognized as Safe (GRAS) chemical, and in most countries it has been approved for use in different food products as an antimicrobial agent (Fallik and others 1994; Sapers and Simmons 1998). In fact, some $\mathrm{H}_{2} \mathrm{O}_{2}$-containing disinfectants approved by ministries of health in Europe and Israel are still used for disinfection of drinking water, foods, and food contact surfaces as an alternative to chlorine (Fallik and others 1994). The United States Food and Drug Administration (FDA) has approved the use of $\mathrm{H}_{2} \mathrm{O}_{2}$ for the treatment of milk for use in cheese, for the preparation of modified whey and thermophile-free starch (CFR 2004), and for the disinfection of red meat carcasses (Mermelstein 2001). However, the FDA requires that residual $\mathrm{H}_{2} \mathrm{O}_{2}$ be removed by appropriate physical and chemical means during processing (CFR 2004). The United States Dept. of Agriculture (USDA) also allows the use of $\mathrm{H}_{2} \mathrm{O}_{2}$ for the pasteurization of egg white (Muriana 1997). Moreover, the Environmental Protection Agency now allows the use of $\leq 1 \% \mathrm{H}_{2} \mathrm{O}_{2}$ to all postharvest agricultural food commodities, from the requirement of tolerance (CFR 2003).

Recently, we investigated the application of hot rehydration, liquid phase $\mathrm{H}_{2} \mathrm{O}_{2}$ disinfection, and cold storage in combination to produce IM sun-dried figs at $28 \%$ to $29 \%$ moisture content (Demirbüker and others 2004). In that study, the moisture content of sundried figs was brought to the desired range by rehydrating them in the presence of $2.5 \% \mathrm{H}_{2} \mathrm{O}_{2}$ at $80{ }^{\circ} \mathrm{C}$ for $16 \mathrm{~min}$. This treatment reduced the total mesophilic aerobic load of figs to a minimum $90 \%$. Also, due to bleaching of brown pigments in figs by $\mathrm{H}_{2} \mathrm{O}_{2}$, light-colored IM products were obtained. Moreover, the application of hot 
rehydration caused partial inactivation of PME in figs and reduced the softening and loss of desired gummy texture of IM figs cold stored for 3 mo. During cold storage of disinfected IM figs, the major problem observed was the physical defects that occurred by the decomposition of residual $\mathrm{H}_{2} \mathrm{O}_{2}$ to $\mathrm{O}_{2}$ by the action of in situ catalase. The tiny gas bubbles formed and trapped within viscous fruit flesh caused a substantial increase (blowing) in the volume of some figs during storage. Also, in some other figs, the gas formed exhausted from the fruit eye and this caused the accumulation of a white foam at this location. Thus, to reduce their contact period with $\mathrm{H}_{2} \mathrm{O}_{2}$, we rehydrated figs with 2-step procedures conducted 1st in $2.5 \% \mathrm{H}_{2} \mathrm{O}_{2}$ solution at $80{ }^{\circ} \mathrm{C}$ for various times and then in hot water at the same temperature until the desired moisture content was achieved. By using this technique, we determined some suitable treatment times that eliminate undesirable physical defects in IM figs during cold storage and reduce residual $\mathrm{H}_{2} \mathrm{O}_{2}$ to levels that can be eliminated by the in situ catalase at reasonable time periods (Demirbüker and others 2004). In this study, we investigated the effects of developed 2-stage rehydration procedures on microbial load, color, PME activity, and texture of IM sun-dried figs during cold storage. Also, we determined the stability of residual $\mathrm{H}_{2} \mathrm{O}_{2}$ in IM figs, tested the potential application of a residue elimination procedure, and evaluated the possible effects of $\mathrm{H}_{2} \mathrm{O}_{2}$ on health benefits of IM figs by determining the antioxidant activities of disinfected samples.

\section{Materials and Methods}

\section{Materials}

Sun-dried figs (cultivar Sarilop from Aydin, Turkey) were supplied by TARIS, (Izmir, Turkey), the cooperative for marketing agricultural products grown in the Aegean region. The citrus pectin (galacturonic acid content, 79\%; methoxy content, 8\%) and ABTS [2,2-azino-bis-(3-ethylbenz-thiazoline-6-sulfonic acid)] was purchased from Sigma Chemical Co. (St. Louis, Mo., U.S.A.). $\mathrm{H}_{2} \mathrm{O}_{2}$ (30\%, extra pure), plate count agar (PCA), potato dextrose agar (PDA), and $\mathrm{H}_{2} \mathrm{O}_{2}$ test strips were obtained from Merck (Darmstadt, Germany). The chloramphenicol antibiotic was obtained from Oxoid (Hampshire, England).

\section{Rehydration and storage studies}

To find the rehydration times required to bring IM figs to approximately $30 \%$ moisture content at $30^{\circ}$ and $80^{\circ} \mathrm{C}$, the rehydration curves of samples were determined in a circulating water bath (Polyscience, Model 71, Niles, Ill., U.S.A.) as described in Demirbüker and others (2004). The initial moisture content of figs was determined by the standard vacuum oven method of AOAC (nr 934.06) for dried fruits (AOAC 1996). During rehydration studies, the temperature profiles of some figs were also determined by placing a 0.9-mm-dia thermocouple in their geometric center and by using a portable temperature recorder (Cole Parmer, DualLogR, Vernon Hills, Ill., U.S.A.).

To obtain the IM figs used in storage experiments, 1 - to $1.2-\mathrm{kg}$ figs were rehydrated at the indicated temperatures. The rehydrations in water at $30^{\circ}$ (for $51 \mathrm{~min}$ ) or $80^{\circ} \mathrm{C}$ (for $16 \mathrm{~min}$ ) were conducted in 1 step. However, when $\mathrm{H}_{2} \mathrm{O}_{2}$ was used as disinfectant, the rehydrations were conducted $1 \mathrm{st}$ in $2.5 \% \mathrm{H}_{2} \mathrm{O}_{2}$ solutions at $80^{\circ} \mathrm{C}$ for 4 or $8 \mathrm{~min}$ and then in water at $80^{\circ} \mathrm{C}$ for 12 or $8 \mathrm{~min}$, respectively. To prevent its degradation, the $\mathrm{H}_{2} \mathrm{O}_{2}$ was added to hot water in baths just before immersion of samples. The figs, drained and cooled at room temperature, were then spread over trays and incubated 12 $\min$ at $100^{\circ} \mathrm{C}$ in a forced hot air oven to remove free water from their surface. At the 6 th min of drying, the figs were turned over to obtain homogeneous drying. This treatment resulted in $1.38 \% \pm 0.28 \%$ moisture loss from the figs and brought their moisture content to the $28 \%$ to $29 \%$ range. The samples were then separated into 300 to 500 -g groups, and each group was put into zipped polyethylene bags and cold stored between $4^{\circ} \mathrm{C}$ and $7{ }^{\circ} \mathrm{C}$ for 3.5 or 5 mo. All rehydrations were repeated for 3 times, and the results of microbiological tests were given separately for each trial. The samples used in the determination of microbial load, PME activity, residual $\mathrm{H}_{2} \mathrm{O}_{2}$, and antioxidant activity were prepared by taking approximately the same amount of pieces from a minimum of 10 figs.

\section{Microbial load}

For microbiological analysis, 50-g fig samples were put into flasks containing $200 \mathrm{~mL} 0.1 \%(\mathrm{w} / \mathrm{w})$ peptone water. The flasks were shaken by hand for $2 \mathrm{~min}$, incubated for $5 \mathrm{~min}$ at room temperature, and further shaken 9 to 10 times before $0.1-\mathrm{mL}$ samples were spread onto the surface of agar plates. Serial dilutions were performed when needed by using $0.1 \%$ peptone water. For counting osmotrophs, $20 \%$ sucrose was included to extraction and dilution mediums. The total mesophilic aerobic microorganisms and yeasts and molds were enumerated by using PCA and PDA (supplemented with $100 \mathrm{mg} / \mathrm{L}$ chloramphenicol) agars, respectively. The PCA plates were incubated at $35^{\circ} \mathrm{C}$ for $48 \mathrm{~h}$, whereas PDA plates were incubated at $25^{\circ} \mathrm{C}$ to $28{ }^{\circ} \mathrm{C}$ for $5 \mathrm{~d}$. The averages of 3 or 5 plate counts were used in microbiological analysis.

\section{PME activity}

PME activity was determined in IM fig homogenates by the titrimetric method given in Demirbüker and others (2004). The enzyme activities were expressed as percent initial activity or $\mu \mathrm{mol}$ $\mathrm{COOH}$ groups liberated per minute per gram of figs. All activity measurements were done as 3 replicates and 3 repetitions.

\section{Texture}

For the determination of texture, rehydrated and cold-stored IM figs were analyzed by hand or fruit hardness tester. In tests conducted by hand, (1) the figs were examined by the classical thumb test to detect whether they softened; (2) the figs were halved and their flesh was squeezed by using thumb and forefinger to detect any sticky and gel-like structure formation; (3) the internal surface of halved figs was smoothly rubbed with the thumb to see whether it rubbed off from the peels easily. All tests were performed by the same trained person by using approximately 50 figs for each of the rehydration procedures. For tests conducted by a fruit hardness tester (Nippon-Model FHR-5, Tokyo, Japan), we used a cone-type tip (12-mm base dia, 10-mm height). Before the penetrations, the figs were shaped by hand as discs to obtain a flat surface. In the disk-shaped fruits, the fruit eye and neck were always set to be at the edges and the penetrations were done around the center of fruits at 6 points. To determine the average firmness, minimum 288 penetrations were obtained from a fig group.

\section{Residual $\mathrm{H}_{2} \mathrm{O}_{2}$}

The residual $\mathrm{H}_{2} \mathrm{O}_{2}$ was determined by using semiquantitative test strips, which can detect $\mathrm{H}_{2} \mathrm{O}_{2}$ in the range of 1 to $100 \mathrm{mg} / \mathrm{L}$. During tests, $25 \mathrm{~g}$ of refrigerated fig sample was homogenized with $200 \mathrm{~mL}$ cold water for $1.5 \mathrm{~min}$ in a blender (Waring, New Hartford, Conn., U.S.A.; no load speed, $18000 \mathrm{rpm}$ ). To prevent the degradation of residual $\mathrm{H}_{2} \mathrm{O}_{2}$ by in situ catalase, a test strip was immediately dipped into the slurries. The concentration of the residual $\mathrm{H}_{2} \mathrm{O}_{2}$, determined by comparing the intensity of blue color developed on test strips and color-concentration scale provided with the test strips, was given as milligrams per $100 \mathrm{~g}$ of IM figs. 


\section{Color}

The effect of $\mathrm{H}_{2} \mathrm{O}_{2}$ and storage time on fig color was monitored by taking the photographs of packed figs with a digital camera (Sony, DCR-PC115E, Japan).

\section{Antioxidant activity}

The antioxidant activities of IM figs were determined spectrophotometrically (Shimadzu, Model 2450, Kyoto, Japan) according to the method of Re and others (1999) by monitoring ABTS radical cation decolorization caused by test samples at $734 \mathrm{~nm}$. The reaction mixture was formed by mixing $2 \mathrm{~mL}$ potassium persulfate oxidized ABTS solution in phosphate buffered saline (PBS) at $\mathrm{pH} 7.4$ and 10 or $20 \mu \mathrm{L}$ of extract (or $20 \mu \mathrm{L}$ of Trolox [0.01 to $0.03 \mu \mathrm{mol}$ in reaction mixture] to prepare the standard curves). The decrease in absorbance was monitored for $15 \mathrm{~min}$. The results were calculated as area under the curve (AUC) and Trolox equivalent antioxidant capacity (TEAC) values and expressed as $\mu \mathrm{mol}$ Trolox/100 g IM figs To calculate the AUC, the percent inhibition/concentration values for the extracts and Trolox were plotted separately against test periods $(1,3,6,9,12,15 \mathrm{~min})$. The ratio of the areas of curves for extracts and Trolox was used to calculate the AUC value. The TEAC values were calculated form the inhibition (for a 6-min test period) against concentration curves. For the extraction of antioxidant compounds, the method applied to raisins by Yeung and others (2003) was used with slight modifications. Briefly, $20 \mathrm{~g}$ of chilled IM fig sample was homogenized with $180 \mathrm{~mL}, 80 \%(\mathrm{v} / \mathrm{v})$ cold aqueous acetone for $3 \mathrm{~min}$. The homogenate, filtered through Whatman $\mathrm{nr}$ 1 under vacuum by using a Buhner funnel, was transferred to an ice water bath and used immediately for the determination of antioxidant activity. The IM fig samples rehydrated in water were analyzed for antioxidant activity after rehydration, immediately after the oven treatment and cooling. The samples treated with $\mathrm{H}_{2} \mathrm{O}_{2}$, on the other hand, were analyzed for antioxidant activity after they were cold stored 1.5 to $3 \mathrm{wk}$, until the residual $\mathrm{H}_{2} \mathrm{O}_{2}$ in IM figs dropped below $0.9 \mathrm{mg} / 100 \mathrm{~g}$. All measurements were conducted 3 times.

\section{Statistical analysis}

The effects of 2 factors, rehydration conditions and storage time, on total mesophilic aerobic count of IM figs were determined by analyzing data with analyses of variance (ANOVA). A significant effect was concluded if results showed that $P \leq 0.05$. When no total mesophilic aerobic counts were obtained for the disinfected samples, the highest possible number (8 colony-forming units [CFU]/ g) was used in statistical analysis to evaluate the effectiveness of a treatment. Because of the very low fungal counts obtained, the total yeast and mold counts could not be analyzed statistically.

\section{Results and Discussion}

\section{The effect of hot rehydration and cold storage on microbial load}

In this study, the times determined from the rehydration curves to reach $30 \%$ moisture content were $51 \mathrm{~min}$ and $16 \mathrm{~min}$ at $30^{\circ} \mathrm{C}$ and $80{ }^{\circ} \mathrm{C}$, respectively (Figure 1). However, after the oven treatment, the moisture content of IM figs reduced to $28 \%$ to $29 \%$.

The effect of hot rehydration at $80^{\circ} \mathrm{C}$ on total mesophilic aerobic counts and yeast and mold counts of IM figs cold-stored for 1 and 3 mo was investigated in our laboratory before (Demirbüker and others 2004). In that study, it was found that the hot rehydration and 3-mo cold storage do not have any significant effects on the microbial load of IM figs. In this study, the IM figs rehydrated at $80^{\circ} \mathrm{C}$ were cold-stored for 3.5 and 5 mo. However, statistical analy- sis indicated that the hot rehydration at $80{ }^{\circ} \mathrm{C}$ and longer storage periods did not also have a significant effect on the total mesophilic aerobic load of IM figs $(P>0.05)$ (Table 1$)$. The initial total yeast and mold counts of IM figs were quite low (Table 2). However, it seems that a certain reduction occurred in the number of fungi by hot rehydration at $80^{\circ} \mathrm{C}$ (no counts were obtained for samples initially). Except the 3rd trial of IM figs rehydrated at $80^{\circ} \mathrm{C}$, the samples maintained their low total yeast and mold counts during 5 mo of cold storage.

\section{The effect of hot rehydration in presence of $\mathrm{H}_{2} \mathrm{O}_{2}$ and cold storage on microbial load}

The initial total mesophilic aerobic load of IM figs may be reduced almost $90 \%$ by rehydrating them in $2.5 \% \mathrm{H}_{2} \mathrm{O}_{2}$ for $16 \mathrm{~min}$ (Demirbüker and others 2004). However, this treatment leaves too much residual $\mathrm{H}_{2} \mathrm{O}_{2}$ in IM fig tissues and causes some physical defects (blowing, foam formation) during cold storage. In this study, to reduce the residual $\mathrm{H}_{2} \mathrm{O}_{2}$, sun-dried figs were rehydrated 1st in $2.5 \% \mathrm{H}_{2} \mathrm{O}_{2}$ at $80^{\circ} \mathrm{C}$ for 4 or $8 \mathrm{~min}$ and then in water at $80^{\circ} \mathrm{C}$ for 12 or $8 \mathrm{~min}$, respectively. For $0-\mathrm{mo}, 3.5 \mathrm{mo}$, and 5 mo storage periods, the comparison of the total mesophilic aerobic counts of $\mathrm{H}_{2} \mathrm{O}_{2}$ treated samples with those of controls suggested that 8-min $\mathrm{H}_{2} \mathrm{O}_{2}$ treatment reduces the microbial load of IM figs significantly $(P<0.05)$. In contrast, 4-min $\mathrm{H}_{2} \mathrm{O}_{2}$ treatment did not cause a significant change in the total mesophilic aerobic load of IM figs $(P>0.05)(\mathrm{Ta}-$ ble 1).

On the other hand, for 0-mo, 3.5-mo, and 5-mo counts, the differences among the total mesophilic aerobic counts of IM figs rehydrated with $(4+12$ or $8+8 \mathrm{~min})$ or without the presence of $\mathrm{H}_{2} \mathrm{O}_{2}$ at $80^{\circ} \mathrm{C}$ for $16 \mathrm{~min}$ were found to be insignificant $(P>0.05)$. In all these statistical analyses, the effect of storage time on total mesophilic aerobic loads was also found to be insignificant. Moreover, the IM figs treated with $\mathrm{H}_{2} \mathrm{O}_{2}$ maintained their low total yeast and mold counts during 5 mo of cold storage (Table 2).

\section{PME activity}

PME plays a central role in the softening of fruits and vegetables by reducing the degree of pectin methylation and making it a sub-

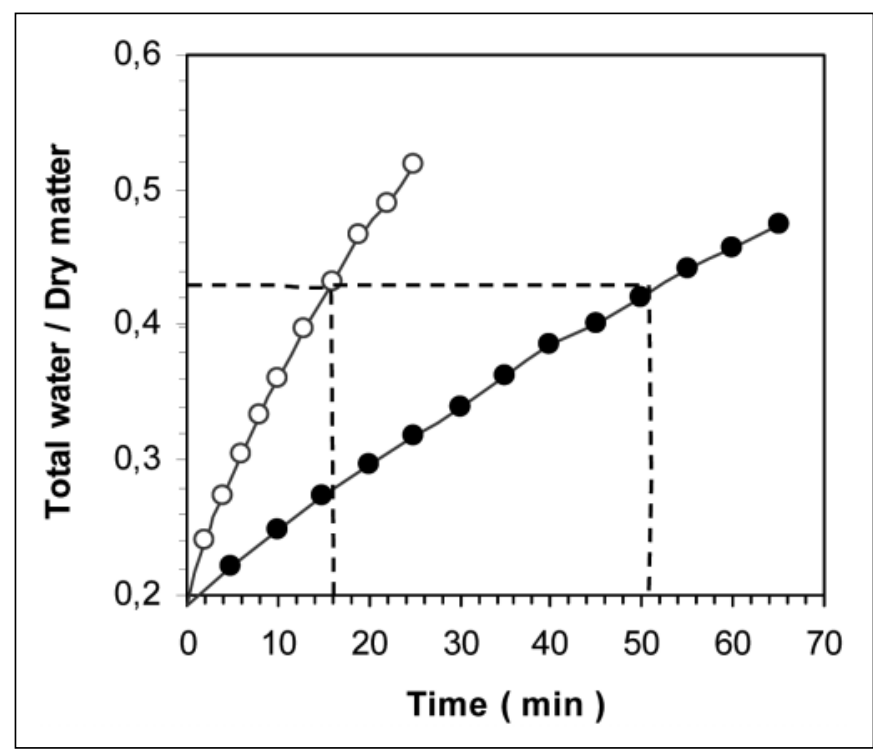

Figure 1-Rehydration curves of sun-dried figs (the percent initial moisture content of figs was $16.1 \pm 0.07) ; 30^{\circ} \mathrm{C}(0)$; $80^{\circ} \mathrm{C}(\mathrm{O})$ 
Table 1-Effect of hot rehydration at $80^{\circ} \mathrm{C}$ alone or in combination with $\mathrm{H}_{2} \mathrm{O}_{2}$ on total mesophilic aerobic count of intermediate moisture sun-dried figs during cold storage

Total mesophilic aerobic count $\log _{10}(\mathrm{CFU} / \mathrm{g})$

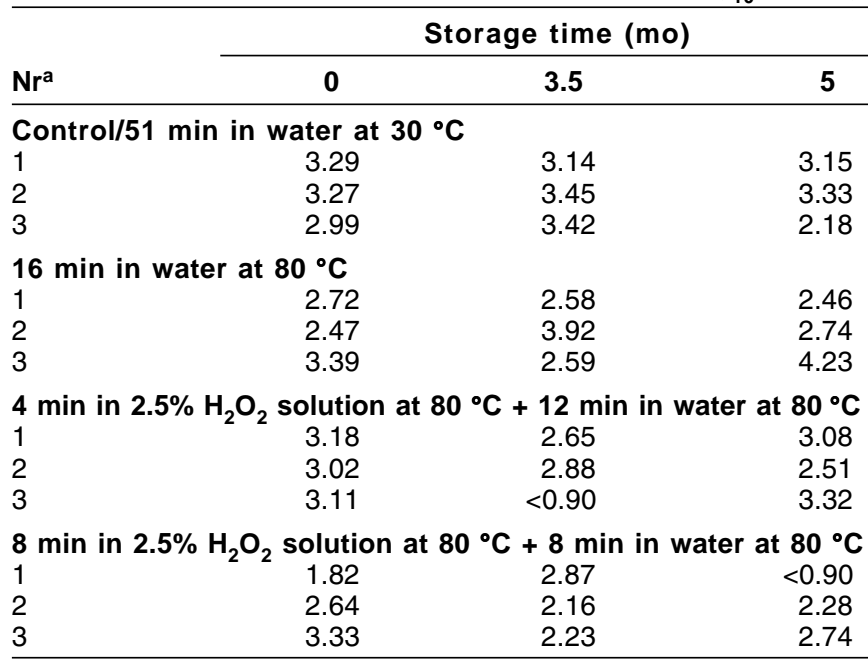

aThe number of separate rehydration trials (replicates). CFU = colony-forming units.

Table 2-The effect of hot rehydration at $80{ }^{\circ} \mathrm{C}$ alone or in combination with $\mathrm{H}_{2} \mathrm{O}_{2}$ on total yeast and mold count of intermediate moisture sun-dried figs during cold storage

\begin{tabular}{|c|c|c|c|c|c|c|}
\hline & \multicolumn{6}{|c|}{ Total yeast and mold count $(\mathrm{CFU} / \mathrm{g})^{\mathrm{b}}$} \\
\hline \multirow[b]{4}{*}{$\mathrm{Nr}^{\mathrm{a}}$} & \multicolumn{6}{|c|}{ Isolation and dilution medium } \\
\hline & $0.1 \%$ & epton & ter & $\begin{array}{c}0.1 \\
\text { conta }\end{array}$ & $\begin{array}{l}\text { eptone } \\
\text { g } 20 \%\end{array}$ & $\begin{array}{l}\text { ter } \\
\text { crose }\end{array}$ \\
\hline & \multicolumn{6}{|c|}{ Storage time (mo) } \\
\hline & 0 & 3.5 & 5 & 0 & 3.5 & 5 \\
\hline $\begin{array}{l}\text { Con } \\
1 \\
2 \\
3\end{array}$ & $\begin{array}{c}1 \text { min } \\
333 \\
160 \\
13\end{array}$ & $\begin{array}{c}\text { water } \\
40 \\
27 \\
27\end{array}$ & $\begin{array}{r}0^{\circ} \mathbf{C} \\
27 \\
27 \\
<13\end{array}$ & $\begin{array}{r}13 \\
67 \\
<13\end{array}$ & $\begin{array}{r}<13 \\
27 \\
27\end{array}$ & $\begin{array}{l}<13 \\
<13 \\
<13\end{array}$ \\
\hline $\begin{array}{l}16 r \\
1 \\
2 \\
3\end{array}$ & $\begin{array}{l}\text { wate } \\
<13 \\
<13 \\
<13\end{array}$ & $\begin{array}{r}80^{\circ} \mathrm{C} \\
13 \\
<13 \\
<13\end{array}$ & $\begin{array}{r}<13 \\
27 \\
493\end{array}$ & $\begin{array}{l}<13 \\
<13 \\
<13\end{array}$ & $\begin{array}{l}27 \\
13 \\
67\end{array}$ & $\begin{array}{l}<13 \\
<13 \\
107\end{array}$ \\
\hline $\begin{array}{l}4 \mathrm{~m} \\
1 \\
2 \\
3\end{array}$ & $\begin{array}{l}.5 \% \mathbf{H} \\
<13 \\
<13 \\
53\end{array}$ & $\begin{array}{c}2 \text { solut } \\
13 \\
13 \\
13\end{array}$ & $\begin{array}{r}180 \\
<13 \\
<13 \\
13\end{array}$ & $\begin{array}{r}12 \mathbf{~ m} \\
13 \\
<13 \\
53\end{array}$ & $\begin{array}{l}\text { n wate } \\
<13 \\
<13 \\
80\end{array}$ & $\begin{array}{r}80^{\circ} \mathbf{C} \\
<13 \\
13 \\
13\end{array}$ \\
\hline $\begin{array}{l}8 \mathrm{~m} \\
1 \\
2 \\
3\end{array}$ & $\begin{array}{r}.5 \% \\
<13 \\
<13 \\
27\end{array}$ & $\begin{array}{r}\text { 2 solu } \\
27 \\
<13 \\
13\end{array}$ & $\begin{array}{r}\text { at } 80 \\
<13 \\
<13 \\
13\end{array}$ & $\begin{array}{r}+8 \mathbf{~ m} \\
<13 \\
13 \\
53\end{array}$ & $\begin{array}{l}\text { wate } \\
<13 \\
<13 \\
<13\end{array}$ & $\begin{array}{r}80{ }^{\circ} \mathbf{C} \\
<13 \\
13 \\
13\end{array}$ \\
\hline
\end{tabular}

aThe number of separate rehydration trials (replicates).

b Because of very low counts, the logarithms of values were not taken. CFU = colony-forming units.

strate for polygalacturonases $(\mathrm{PG})$ that depolymerize the pectin (Marangoni and others 1995; Artes and others 1996). After rehydration, the PME activity of IM figs rehydrated with or without the presence of $\mathrm{H}_{2} \mathrm{O}_{2}$ at $80^{\circ} \mathrm{C}$ was $25 \%$ to $30 \%$ less than those of control IM figs rehydrated in water at $30^{\circ} \mathrm{C}$ (Table 3). However, because of slight and/or moderate changes in PME activity of samples during cold storage, the difference between the PME activities of control and heat-treated IM figs reduced to between $14 \%$ to $20 \%$ and $19 \%$ to $21 \%$ at the end of 3.5 and $5 \mathrm{mo}$, respectively.
Table 3-Residual pectin methylesterase (PME) activities in intermediate-moisture sun-dried figs rehydrated at different conditions and cold-stored for different time periods

\begin{tabular}{|c|c|c|c|}
\hline \multirow{3}{*}{$\begin{array}{l}\text { Type of } \\
\text { rehydration }\end{array}$} & \multicolumn{3}{|c|}{ Activity $(\mu \mathrm{mol} \mathrm{COOH} / \mathrm{min} / \mathrm{g})$} \\
\hline & \multicolumn{3}{|c|}{ Storage time (mo) } \\
\hline & 0 & 3.5 & 5 \\
\hline $\begin{array}{l}\text { Control/51 min } \\
\text { in water at } 30^{\circ} \mathrm{C}\end{array}$ & $25.5 \pm 1.2(100)$ & $23.7 \pm 2.1(100)$ & $25.0 \pm 1.4(100)$ \\
\hline $\begin{array}{l}16 \text { min in water } \\
\text { at } 80^{\circ} \mathrm{C}\end{array}$ & $19.1 \pm 1.0(75)^{\mathrm{a}}$ & $20.3 \pm 1.0$ & $19.7 \pm 1.8(79)$ \\
\hline $\begin{array}{l}4 \text { min in } 2.5 \% \mathrm{H}_{2} \mathrm{O}_{2} \\
\text { solution at } 80{ }^{\circ} \mathrm{C} \\
+12 \text { min in water } \\
\text { at } 80^{\circ} \mathrm{C}\end{array}$ & $19.1 \pm 8.9(75)$ & $19.0 \pm 0.9(80)$ & $20.2 \pm 1.6(81)$ \\
\hline $\begin{array}{l}8 \text { min in } 2.5 \% \mathrm{H}_{2} \mathrm{O}_{2} \\
\text { solution at } 80{ }^{\circ} \mathrm{C} \\
+8 \text { min in water } \\
\text { at } 80{ }^{\circ} \mathrm{C}\end{array}$ & $17.8 \pm 1.5(70)$ & $20.3 \pm 1.2(86)$ & $19.9 \pm 0.6(80)$ \\
\hline
\end{tabular}

aPercent activity as compared with corresponding control (for values at each column, the activity of PME in figs rehydrated at $80^{\circ} \mathrm{C}$ with or without the presence of $\mathrm{H}_{2} \mathrm{O}_{2}$ was compared with the activity of PME in controls stored for the same time period).

Table 4-Some textural properties of intermediate-moisture sun-dried figs cold-stored for different time periods

\begin{tabular}{|c|c|c|c|c|}
\hline \multirow{3}{*}{$\begin{array}{l}\text { Type of } \\
\text { rehydration }\end{array}$} & \multicolumn{2}{|c|}{ Firmness (kg) } & \multicolumn{2}{|c|}{$\begin{array}{l}\% \text { fruits that flesh } \\
\text { can easily be } \\
\text { rubbed off from the } \\
\text { peels with thumb }\end{array}$} \\
\hline & \multicolumn{4}{|c|}{ Storage time (mo) } \\
\hline & 3.5 & 5 & 3.5 & 5 \\
\hline $\begin{array}{l}\text { Control/51 min } \\
\text { in water at } 30{ }^{\circ} \mathrm{C}\end{array}$ & $\begin{array}{c}0.35 \pm 0.10 \\
(294)^{\mathrm{a}}\end{array}$ & $\begin{array}{c}0.29 \pm 0.07 \\
(318)\end{array}$ & $\begin{array}{l}51 \\
(49)^{\mathrm{b}}\end{array}$ & $\begin{array}{l}77 \\
(53)\end{array}$ \\
\hline $\begin{array}{l}16 \text { min in } \\
\text { water at } 80^{\circ} \mathrm{C}\end{array}$ & $\begin{array}{c}0.31 \pm 0.06 \\
\quad(318)\end{array}$ & $\begin{array}{l}0.25 \pm 0.04 \\
\quad(288)\end{array}$ & $\begin{array}{c}48 \\
(48)\end{array}$ & $\begin{array}{c}60 \\
(49)\end{array}$ \\
\hline $\begin{array}{l}4 \text { min in } 2.5 \% \mathrm{H}_{2} \mathrm{O}_{2} \\
\text { solution at } 80^{\circ} \mathrm{C} \\
+12 \text { min in water } \\
\text { at } 80^{\circ} \mathrm{C}\end{array}$ & $\begin{array}{l}0.34 \pm 0.05 \\
\quad(288)\end{array}$ & $\begin{array}{l}0.32 \pm 0.05 \\
\quad(306)\end{array}$ & $\begin{array}{c}40 \\
(48)\end{array}$ & $\begin{array}{l}53 \\
(51)\end{array}$ \\
\hline $\begin{array}{l}8 \mathrm{~min} \text { in } 2.5 \% \mathrm{H}_{2} \mathrm{O}_{2} \\
\text { solution at } 80{ }^{\circ} \mathrm{C}+ \\
8 \text { min in water at } 80\end{array}$ & $\begin{array}{l}0.45 \pm 0.11 \\
{ }^{\circ} \mathrm{C}\end{array}$ & $\begin{array}{l}0.32 \pm 0.05 \\
\quad(306)\end{array}$ & $\begin{array}{l}31 \\
(51)\end{array}$ & $\begin{array}{l}55 \\
(51)\end{array}$ \\
\hline
\end{tabular}

aNumber of penetrations.

bNumber of fruits tested.

\section{Texture}

After 3.5 mo of cold storage, when IM figs rehydrated in water at $30^{\circ}$ and $80^{\circ} \mathrm{C}$ were examined by the classical thumb test, a softening was detected in most of the IM figs. In 5 mo, figs of both group showed further softening, and most of them lost their volume and become disc-like. The reduction of the firmnesses of these figs was determined also by the fruit hardness tester (Table 4). Thus, it is clear that the partial inactivation of PME by rehydration in water at $80^{\circ} \mathrm{C}$ has almost no benefits to prevent the softening of IM figs coldstored for $3.5 \mathrm{mo}$. Two seasons ago, less softening was observed in IM figs rehydrated at $80{ }^{\circ} \mathrm{C}$ for $16 \mathrm{~min}$ and cold-stored for $3 \mathrm{mo}$ (Demirbüker and others 2004). In that season, the heat treatment caused almost the same amount of PME inactivation. However, the difference between the PME activities of IM figs rehydrated at $30^{\circ}$ and $80^{\circ} \mathrm{C}$ was unchanged by 3 mo of cold storage. Thus, it is likely that the benefit of hot rehydration at $80^{\circ} \mathrm{C}$ on IM fig texture de- 
Table 5-The amounts of residual $\mathrm{H}_{2} \mathrm{O}_{2}$ in intermediate-moisture (IM) sun-dried figs

\begin{tabular}{|c|c|c|c|c|c|c|c|}
\hline \multirow[b]{3}{*}{ Type of rehydration } & \multicolumn{7}{|c|}{ Residual $\mathrm{H}_{2} \mathrm{O}_{2}$ (mg/100 g IM figs) } \\
\hline & \multicolumn{7}{|c|}{ Storage time $(d)$} \\
\hline & 0 & 2 & 5 & 9 & 14 & 16 & 23 \\
\hline $8 \mathrm{~min}$ in $2.5 \% \mathrm{H}_{2} \mathrm{O}_{2}$ solution at $80^{\circ} \mathrm{C}+8 \mathrm{~min}$ in water at $80^{\circ} \mathrm{C}$ & 169 & 27 to 89 & 27 & 9 & 0.9 to 2.7 & 0.9 & $<0.9$ \\
\hline \multicolumn{8}{|c|}{$8 \mathrm{~min}$ in $2.5 \% \mathrm{H}_{2} \mathrm{O}_{2}$ solution at $80^{\circ} \mathrm{C}+8 \mathrm{~min}$ in water at $80^{\circ} \mathrm{C}$ (containing 50 to $500 \mathrm{mg} / \mathrm{L}$ iron (II) sulfate +2 to $10 \mathrm{~g} / \mathrm{L}$ ascorbic acid) } \\
\hline $50 \mathrm{mg} / \mathrm{L}$ iron (II) sulfate $+2 \mathrm{~g} / \mathrm{L}$ ascorbic acid & 27 to 89 & 27 & 9 to 27 & 9 & 2.7 & 0.9 & $<0.9$ \\
\hline $500 \mathrm{mg} / \mathrm{L}$ iron (II) sulfate $+10 \mathrm{~g} / \mathrm{L}$ ascorbic acid & $<0.9$ & - & - & - & - & - & - \\
\hline
\end{tabular}

pends on seasonal changes in the stability and/or properties of PME enzymes during cold storage. The activities of other pectinases and molecular properties of pectin may also be very important on the development of undesirable textural changes. In the future, the addition of suitable amounts of $\mathrm{CaCl}_{2}$ to rehydration water may also be tested to stabilize pectin and prevent these undesirable textural changes.

After $3.5 \mathrm{mo}$ of cold storage, the IM figs rehydrated for $4 \mathrm{~min}$ in $2.5 \% \mathrm{H}_{2} \mathrm{O}_{2}$ at $80^{\circ} \mathrm{C}$ had almost the same firmness with the control IM figs rehydrated in water at $30^{\circ} \mathrm{C}$. However, unlike in controls, the IM figs rehydrated $4 \mathrm{~min}$ in $\mathrm{H}_{2} \mathrm{O}_{2}$ solution showed almost no further softening by $5 \mathrm{mo}$ of cold storage. The IM figs rehydrated for $8 \mathrm{~min}$ in $2.5 \% \mathrm{H}_{2} \mathrm{O}_{2}$, on the other hand, were considerably firmer than figs in other groups after 3.5 mo of cold storage. In 5 mo, however, the firmness of these IM figs reduced and became almost the same with the firmness of IM figs disinfected 4 min in $\mathrm{H}_{2} \mathrm{O}_{2}$ solution. The IM figs rehydrated 4 or $8 \mathrm{~min}$ in $2.5 \% \mathrm{H}_{2} \mathrm{O}_{2}$ at $80{ }^{\circ} \mathrm{C}$ maintained their volumes and shapes better than the IM figs rehydrated in water at $30^{\circ}$ or $80^{\circ} \mathrm{C}$. Also, the flesh of $\mathrm{H}_{2} \mathrm{O}_{2}$-treated IM figs was more consistent and it could not easily be rubbed off from the peels with the thumb. The control of undesirable textural changes in disinfected IM figs may be related with the $\mathrm{H}_{2} \mathrm{O}_{2}$ catalyzed oxidation of phenolic compounds such as hydroxycinnamates that may affect the firmness of fruits and vegetables by cross-linking and stabilizing the neighboring pectin and other biopolymers in the cell walls (Waldron and others 1997; Faulds and Williamson 1999; Beveridge and others 2000). It was reported that the main enzyme responsible from the oxidation of phenolic compounds is peroxidase that uses $\mathrm{H}_{2} \mathrm{O}_{2}$ as substrate (Faulds and Williamson 1999). Thus, in addition to the direct oxidative effect of $\mathrm{H}_{2} \mathrm{O}_{2}$, enzymatic oxidation is also possible. Further studies are needed to find the exact mechanism of the retained texture in $\mathrm{H}_{2} \mathrm{O}_{2}$ treated figs.

\section{Residual $\mathrm{H}_{2} \mathrm{O}_{2}$}

As indicated before, when too much residual $\mathrm{H}_{2} \mathrm{O}_{2}$ remains in fig tissues, the decomposition of this residue by in situ catalase forms considerable amounts of $\mathrm{O}_{2}$ gas that causes blowing of fruits or foam formation at the fruit eye. Last season, by applying the 2stage rehydrations $(4+8$ or $8+8)$ at $80^{\circ} \mathrm{C}$, we reduced the residual $\mathrm{H}_{2} \mathrm{O}_{2}$ considerably and eliminated the physical defects occurred in IM figs (Demirbüker and others 2004). In that season, the residual $\mathrm{H}_{2} \mathrm{O}_{2}$ in IM figs decomposed in 2 to $4 \mathrm{wk}$. In this season, the residual $\mathrm{H}_{2} \mathrm{O}_{2}$ in IM figs disappeared more rapidly (in 1.5 to $3 \mathrm{wk}$ ) (Table 5). This may be due to the seasonal changes in the activity of in situ catalase that may be affected from the environmental conditions. Also, no foam formation and blowing were observed in IM figs after rehydration and during cold storage. This observation

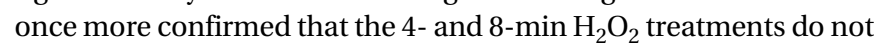

cause any major physical defect in IM figs. During our examinations, the only minor defect detected in IM figs was the tiny gas bubbles that formed and trapped at the depths of viscous fruit flesh, close to the inner part of peel. This defect was detected particularly in 8-min $\mathrm{H}_{2} \mathrm{O}_{2}$-treated IM figs when fruit seeds were gently removed with the thumb and flesh surface was observed with a minimum 3-fold magnification.

In this study, the potential application of a chemical method was also tested to eliminate residual $\mathrm{H}_{2} \mathrm{O}_{2}$ in shorter time periods. It is well known that in the presence of $\mathrm{Fe}^{+2}$ ions, $\mathrm{H}_{2} \mathrm{O}_{2}$ degraded more rapidly to its reactive and less stable free radicals with a reaction called the Fenton reaction $\left(\mathrm{H}_{2} \mathrm{O}_{2}+\mathrm{Fe}^{+2} \rightarrow \mathrm{Fe}^{+3}+\mathrm{OH}^{-}+{ }^{\bullet} \mathrm{OH}\right)(\mathrm{Ney}-$ ens and Baeyens 2003). Thus, to degrade residual $\mathrm{H}_{2} \mathrm{O}_{2}$, we tested adding 50 to $500 \mathrm{mg} / \mathrm{L}$ iron (II) sulfate to water at $80^{\circ} \mathrm{C}$, used at the 2nd stage of rehydration. At $80^{\circ} \mathrm{C}$, the $\mathrm{Fe}^{+2}$ ions in the medium may be more rapidly turned to $\mathrm{Fe}^{+3}$ by auto oxidation. Thus, iron (II) sulfate was added to water just before dipping fig samples obtained from the 1st stage of rehydration conducted at $80^{\circ} \mathrm{C}$ in $2.5 \%$ $\mathrm{H}_{2} \mathrm{O}_{2}$ solution. To convert the oxidized $\mathrm{Fe}^{+3}$ ions back to $\mathrm{Fe}^{+2}$ ions and increase the amount of $\mathrm{H}_{2} \mathrm{O}_{2}$ degraded, 2 to $10 \mathrm{~g} / \mathrm{L}$ ascorbic acid was also added to rehydration medium.

As seen in Table 5, the use of $50 \mathrm{mg} / \mathrm{L}$ iron (II) sulfate $+2 \mathrm{~g} / \mathrm{L}$ ascorbic acid at the 2nd stage of rehydration reduced the initial residue level in 8-min $\mathrm{H}_{2} \mathrm{O}_{2}$-treated IM figs only slightly. However, when iron (II) sulfate and ascorbic acid concentrations were increased to $100 \mathrm{mg} / \mathrm{L}$ and $3 \mathrm{~g} / \mathrm{L}$, respectively, the decomposition period reduced by almost $1 \mathrm{wk}$. Also, at $150 \mathrm{mg} / \mathrm{L}$ iron (II) sulfate and $4 \mathrm{~g} / \mathrm{L}$ ascorbic acid concentrations, the residual level of $\mathrm{H}_{2} \mathrm{O}_{2}$ in 8-min disinfected IM figs reduced to below $0.9 \mathrm{mg} / 100 \mathrm{~g}$ in almost $1.5 \mathrm{wk}$. This decomposition period for residual $\mathrm{H}_{2} \mathrm{O}_{2}$ is equal to that for residual $\mathrm{H}_{2} \mathrm{O}_{2}$ in 4-min disinfected IM figs. Further increase of iron (II) sulfate to $500 \mathrm{mg} / \mathrm{L}$ and ascorbic acid to $10 \mathrm{~g} / \mathrm{L}$, on the other hand, eliminated residual $\mathrm{H}_{2} \mathrm{O}_{2}$ in IM figs within several hours. However, at this chemical concentrations, the peels of IM figs disturbed and turned to a sticky layer at the surfaces of fruits. The treatment of fruits with $10 \mathrm{~g} / \mathrm{L}$ ascorbic acid alone did not cause the formation of this defect. Thus, it seems that the degradation of peels occurred by the effect of very strong oxidation-reduction reactions at the fruit surface. This study clearly showed the possibility of eliminating residual $\mathrm{H}_{2} \mathrm{O}_{2}$ in disinfected IM figs by redox reactions. However, further studies are needed to optimize the use of iron (II) sulfate and ascorbic acid in combination or alone and to determine the effects of redox reactions on IM fig quality.

\section{Color}

During cold storage, a substantial browning occurred to IM figs rehydrated in water at $30^{\circ} \mathrm{C}$ and $80^{\circ} \mathrm{C}$ (Figure 2). Particularly, the IM figs rehydrated at $80^{\circ} \mathrm{C}$ were darker after 5 mo of cold storage. 
Thus, it is clear that the use of antibrowning agents is essential for heat-treated IM figs. In contrast, at the end of $3.5 \mathrm{mo}$, the IM figs rehydrated for 4 or $8 \mathrm{~min}$ in $2.5 \% \mathrm{H}_{2} \mathrm{O}_{2}$ solution had a light brown to light brown-yellow color. After 5 mo of storage, the IM figs disinfected for 4 min in $\mathrm{H}_{2} \mathrm{O}_{2}$ showed slight darkening. However, 8-min disinfected IM figs were still light colored. Traditionally, the light color of IM or high moisture fruits is maintained by adding 0 to 150 ppm $\mathrm{SO}_{2}$ during their packaging (de Daza and others 1997). However, our previous findings (Demirbüker and others 2004) and the results of this study clearly showed that the use of sulfites is not necessary when IM figs are disinfected by $\mathrm{H}_{2} \mathrm{O}_{2}$.

\section{Antioxidant activity}

In the literature, it was reported that some antioxidant Maillard reaction products (MRPs) form during heat processing of food (Yoshimura and others 1997; Nicoli and others 1999). However, the results obtained in this study showed that the heat treatment at 80 ${ }^{\circ} \mathrm{C}$ for 16 min does not affect the antioxidant activity of IM figs (Table 6). However, heat-treated IM figs showed further browning at the end of 5 mo. Thus, the antioxidant activity of heat-treated IM figs may increase during cold storage. On the other hand, treatment of figs with $\mathrm{H}_{2} \mathrm{O}_{2}$ at $80^{\circ} \mathrm{C}$ for 4 or 8 min increased the AUC and TEAC values of IM figs slightly. It is interesting to note that the antioxidant activity of IM figs increased by exposure to $\mathrm{H}_{2} \mathrm{O}_{2}$. It is likely that heating in the presence of $\mathrm{H}_{2} \mathrm{O}_{2}$ accelerated the production of some intermediary antioxidant MRPs that formed by oxidative changes. It is known that the oxidants affect some steps of the Maillard reaction. For example, strecker degradation, the degradation of amino acids to aldehydes, ammonia, and carbon dioxide by carbonyl compounds, may also occur by the effect of strong oxidants such as hydrogen peroxide (Davidek and others 1990). The oxidized phenolic compounds may also show a strecker activity (Davidek and others 1990) or they may form some derivatives that have greater antioxidant activities (Hagerman and others 1998; Antolovich and others 2004). Moreover, because a considerable bleaching occurred by $\mathrm{H}_{2} \mathrm{O}_{2}$ treatment, the antioxidant compounds may also be the degradation products of the brown-colored melanoidins.

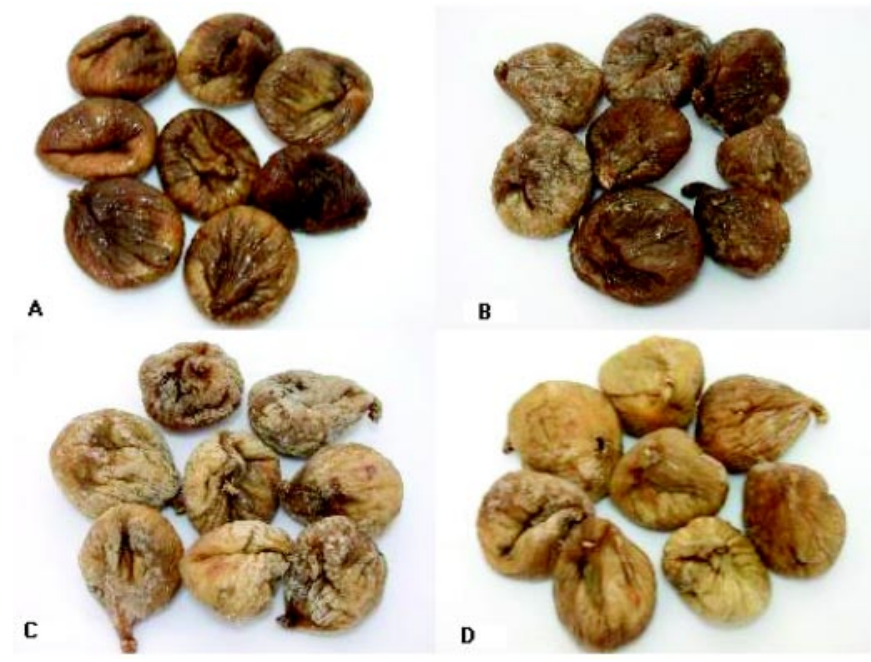

Figure 2-Photographs of intermediate moisture sun-dried figs after 3.5 mo of cold storage (rehydrated for $51 \mathrm{~min}$ in water at $30{ }^{\circ} \mathrm{C}$ (A); rehydrated for $16 \mathrm{~min}$ in water at $80^{\circ} \mathrm{C}$ (B); rehydrated 1 st for $4 \mathrm{~min}$ (C) or $8 \mathrm{~min}$ (D) in $2.5 \% \mathrm{H}_{2} \mathrm{O}_{2}$ at $80^{\circ} \mathrm{C}$ and then for 12 or $8 \mathrm{~min}$ in water at $80^{\circ} \mathrm{C}$, respectively.)
Table 6-Antioxidant activities of intermediate-moisture (IM) sun-dried figs rehydrated at different conditions ${ }^{a}$

Antioxidant activity ( $\mu$ mol Trolox/100 g IM figs)

Type of rehydration

Control/51 min in water at $30{ }^{\circ} \mathrm{C}$

$16 \mathrm{~min}$ in water at $80^{\circ} \mathrm{C}$ AUC ${ }^{a}$ TEAC ${ }^{b}$

$4 \mathrm{~min}$ in $2.5 \% \mathrm{H}_{2} \mathrm{O}_{2}$ solution at

$80{ }^{\circ} \mathrm{C}+12 \mathrm{~min}^{2}$ in water at $80{ }^{\circ} \mathrm{C}$

$8 \mathrm{~min}$ in $2.5 \% \mathrm{H}_{2} \mathrm{O}_{2}$ solution at

$80^{\circ} \mathrm{C}+8 \mathrm{~min}$ in water at $80^{\circ} \mathrm{C}$

$\begin{array}{rr}988(100) & 991(100) \\ 994(101)^{c} & 984(99) \\ 1130(114) & 1264(128)\end{array}$

$1100(111)$

$1100(111)$

aAUC = area under the curve; bTEAC = Trolox equivalent antioxidant capacity cPercent antioxidant activity as compared with corresponding control.

\section{Conclusions}

$\mathrm{T}$ he 2-stage rehydration conducted 1 st in $2.5 \% \mathrm{H}_{2} \mathrm{O}_{2}$ solution at $80^{\circ} \mathrm{C}$ for $8 \mathrm{~min}$ and then in hot water at the same temperature for $8 \mathrm{~min}$ reduces the microbial load of IM figs, eliminates the need of using $\mathrm{SO}_{2}$ by turning the brown fig color to light brown-yellow, and limits undesirable textural changes. The treatment of figs with $\mathrm{H}_{2} \mathrm{O}_{2}$ increases the antioxidant activity of IM figs slightly. In IM figs, destined for exportation, the times needed for shipping and distribution seem sufficient to eliminate residual $\mathrm{H}_{2} \mathrm{O}_{2}$ only by the action of in situ catalase. The decomposition rate of $\mathrm{H}_{2} \mathrm{O}_{2}$ may be accelerated considerably by the iron (II) sulfate-ascorbic acid residue elimination method. However, further studies should be conducted to evaluate the effect of this residue elimination treatment on IM fig quality.

\section{Acknowledgments}

We thank TARIS, the cooperative for marketing agricultural products grown in Aegean region, for supplying the figs used in this study.

\section{References}

Antolovich M, Bedgood DR, Bishop AG, Jardine D, Prenzler PD, Robards K. 2004. LC-MC Investigation of oxidation products of phenolic antioxidants. J Agric Food Chem 52:962-71.

AOAC.1996. Fruits and fruit products-moisture in dried fruits. In: AOAC official methods of analysis. Nr 934.06. Washington, D.C.: Association of OFficial Analytical Chemistry. p 4.

Artes F, Cano A, Fernandez-Trujillo JP. 1996. Pectolytic enzyme activity during intermittent warming storage of peaches. J Food Sci 61:311-21.

Beveridge T, Loubert E, Harrison JE. 2000. Simple measurement of phenolic esters in plant cell walls. Food Res Int 33:775-83.

Cemeroglu B. 1986. Kurutma teknolojisi. In: Cemeroglu B, Acar J, editors. Meyve ve sebze isleme teknolojisi. Ankara: Gida Teknolojisi Dernegi Yayinlari. 6:365-434. [CFR] Code of Federal Regulations. 2003. Hydrogen peroxide; exemption form the requirement of a tolerance. 40 CFR 180. 1197. Office of the Federal Register. Washington, D.C.: U.S. Government Printing Office.

[CFR] Code of Federal Regulations. 2004. Direct food substances affirmed as generally recognized as safe. 21 CFR 184.1366. Office of the Federal Register. Washington, D.C.: U.S. Government Printing Office.

Davidek J, Velisek J, Pokorny J. 1990. Chemical changes during food processing. New York: Elsevier Science Publishing. p 39-41.

de Daza MST, Alzamora SM, Welti-Chanes J. 1997. Minimally processed high moisture fruit products by combined methods: result of a multinational project. In: Fito P, Ortega-Rodriguez E, Barbosa-Canovas GV, editors. Food engineering. New York: Chapman and Hall. p 161-80.

Demirbüker D, Simsek S, Yemenicioglu A. 2004. Potential application of hot rehydration alone or in combination with hydrogen peroxide to control pectin methylesterase activity and microbial load in cold stored intermediate moisture sun-dried figs. J Food Sci 69:170-8.

Desai UT, Kotecha PM. 1995. Fig. In: Salunkhe DK, Kadam SS, editors. Handbook of fruit science and technology. New York: Marcel Dekker. p 407-17.

El Halouat A, Gourama H, Uyttendaele M, Debereve JM. 1998. Effects of modified atmosphere packaging and preservatives on the shelf-life of high moisture prunes and raisins. Int J Food Microbiol 41:177-84.

Fallik E, Aharoni Y, Grinberg S, Copel A, Klein JD. 1994. Postharvest hydrogen peroxide treatment inhibits decay in eggplant and sweet red pepper. Crop Prot 13:451-4

Faulds CB, Williamson G. 1999. The role of hydroxycinnamates in the plant cell wall. J Sci Food Agric 79:393-5.

Hagerman AE, Riedl KM, Jones GA, Sovik KN, Ritchard NT, Hartzfeld PW, Riechel 
TL. 1998. High molecular weight plant polyphenolics (Tannins) as biological antioxidants. J Agric Food Chem 46:1887-92.

Marangoni AG, Jackman RL, Stanley DW. 1995. Chilling-associated softening of tomato fruit is related to increased pectinmethylesterase activity. J Food Sci 60:1277-81.

Mermelstein NH. 2001. Sanitizing meat. Food Technol 55:64-8.

Muriana PM. 1997. Effect of $\mathrm{pH}$ and hydrogen peroxide on heat inactivation of Salmonella and Listeria in egg white. Food Microbiol 14:11-9.

Neyens E, Baeyens J. 2003. A review of classic Fenton's peroxidation as an advanced oxidation technique. J Hazard Mater 98:33-50.

Nicoli MC, Anese M, Parpinel M. 1999. Influence of processing on the antioxidant properties of fruit and vegetables. Trends Food Sci Tech 10:94-100.

Re R, Pellegrini N, Proteggente A, Pannala A, Yang M, Rice-Evans C. 1999. Antioxidant activity applying an improved ABTS radical cation decolorization assay. Free Rad Bio Med 26:1231-7.

Sapers GM, Simmons GF. 1998. Hydrogen peroxide disinfection of minimally processed fruits and vegetables. Food Technol 52:48-52.

Simmons GF, Smilanick JL, John S, Margosan DA. 1997. Reduction of microbial populations on prunes by vapor-phase hydrogen peroxide. J Food Prot 60:18891.

Waldron KW, Ng A, Parker ML, Parr A. 1997. Ferulic acid dehydrodimers in the cell walls of beta vulgaris and their possible role in texture. J Sci Food Agric $74: 221-8$

Welti-Chanes J, Vergara-Balderas F, Lopez-Malo A. 1997. Minimally processed foods state of the art and future. In: Fito P, Ortega-Rodriguez E, Barbosa-Canovas GV, editors. Food engineering. New York: Chapman and Hall. p 181-212. Yeung CK, Glahn RP, Wu X, Liu RH, Miller DD. 2003. In vitro iron bioavailability and antioxidant activity of raisins. J Food Sci 68:701-5.

Yoshimura Y, Iijima T, Watanabe T, Nakazawa H. 1997. Antioxidative effect of maillard reaction products using glucose-glycine model system. J Agric Food Chem 45:4106-9. 